Citation: S. Farahnaz Talebi, M. Jamal Saharkhiz, M. Jafarkhani Kermani, Y. Sharafi (2021) Polyploidy increases tolerance to salt stress in Anise hyssop (Agastache foeniculum [Pursh.] Kuntze). Caryologia 74(1): 33-41. doi: 10.36253/caryologia-783

Received: December 18, 2019

Accepted: April 26, 2021

Published: July 20, 2021

Copyright:@2021 S. Farahnaz Talebi, M. Jamal Saharkhiz, M. Jafarkhani Kermani, Y. Sharafi. This is an open access, peer-reviewed article published by Firenze University Press (http://www. fupress.com/caryologia) and distributed under the terms of the Creative Commons Attribution License, which permits unrestricted use, distribution, and reproduction in any medium, provided the original author and source are credited.

Data Availability Statement: All relevant data are within the paper and its Supporting Information files.

Competing Interests: The Author(s) declare(s) no conflict of interest.

\section{Polyploidy increases tolerance to salt stress in Anise hyssop (Agastache foeniculum [Pursh.] Kuntze)}

\author{
Seyyedeh Farahnaz Talebi ${ }^{1}$, Mohammad Jamal Saharkhiz ${ }^{2}$, Maryam \\ JAFARKHANI KERMANI ${ }^{3}$, YAVAR SHARAFI ${ }^{4, *}$ \\ ${ }^{1}$ Department of Horticultural Sciences, Faculty of Agriculture, Shiraz University, Shiraz, \\ Iran \\ ${ }^{2}$ Medicinal Plants Processing Research Center, Shiraz University of Medical Sciences, Shi- \\ raz, Iran \\ ${ }^{3}$ Department of Tissue and Cell Culture, Agricultural Biotechnology Research Institute of \\ Iran (ABRII), Agricultural Research, Education and Extension Organization (AREEO), \\ Karaj, Iran, P.O. Box: 31535-1897 \\ ${ }^{4}$ Department of Horticultural Sciences, Shahed University, Tehran, Iran \\ ${ }^{*}$ Corresponding author. E-mail, y.sharafi@shahed.ac.ir
}

\begin{abstract}
Salinization is one of the most serious environmental problems in agriculture. Polyploid induction could increase abiotic stress tolerance in plants. In this study, the effect of different $\mathrm{NaCl}$ concentrations $(0,50,100$ and $150 \mathrm{mM})$ was studied on diploid $(2 x)$ and tetraploid $(4 x)$ plants of anise hyssop (Agastache foeniculum) in vitro. The results indicated that salt stress reduced survival percentage, stem length, and leaf and shoot number in both tetraploid and diploid plants. However, tetraploid plants had better survival and growth rates compared with diploids. The highest antioxidant enzyme activity was observed in the plants treated with $100 \mathrm{mM} \mathrm{NaCl}$, while increasing the salinity to $150 \mathrm{mM} \mathrm{NaCl}$ lowered the activity of antioxidant enzymes significantly. Essential oil content in diploid and tetraploid plants decreased as the concentration of $\mathrm{NaCl}$ was elevated. Also, salinity stress affected the chemical composition of essential oil in both diploid and tetraploid plants. In conclusion, the results indicated that tetraploids showed greater tolerance to salt stress compared with diploids, and polyploidy might be a useful breeding method in anise hyssop to amplify its tolerance to salt stress under soil salinity.
\end{abstract}

Keywords: anise hyssop, essential oil, polyploidy, salt tolerance.

Abbreviations: EO - essential oil; ROS - reactive oxygen species; $\mathrm{O}_{2}{ }^{-}$- superoxide radicals; $\mathrm{H}_{2} \mathrm{O}_{2}$ - hydrogen peroxide; $\mathrm{OH}^{\bullet}$ - hydroxyl radicals; SOD superoxide dismutases; CAT - catalases; APX - ascorbate peroxidases; GST - glutathione S-transferases; GPX - glutathione peroxidases.

\section{INTRODUCTION}

Anise hyssop (Agastache foeniculum) from the family Lamiaceae is as an important medicinal plant. The essential oil (EO) of anise hyssop is mainly 
biosynthesized in its leaves and flowers which contain significant amounts of methyl chavicol. In medicinal plants, secondary metabolites are fundamentally produced by genetic pathways, although environmental factors also strongly influence their biosynthesis (Zhang, 2015). Biotic and abiotic environmental factors, specifically salinity and drought conditions, affect growth parameters, medicinal plants' survival, and their essential oil yield (Heidari et al. 2008, Heydari et al. 2020, sharafi et al. 2017). Podda et al. (2013) stated that salinity is one of the most important abiotic stresses in agriculture affecting the plant growth and agricultural productivity. High levels of soil salinity have toxic effects on the absorption of nutrients from the root system in the plant through osmotic processes which, in turn, reduces essential oil production and modifies their composition in medicinal and aromatic species (Sarmoum et al. 2019). It is essential to determine the environmental factors under which medicinal and aromatic plants offer higher yields and improve quality. High salinity can disturb essential physiological processes due to factors such as water deficits, nutritional imbalance, hyper-osmotic stress, ion imbalance, metabolic disorders, and appearance or disappearance of some proteins which may eventually lead to death (Meng et al. 2016). These culminate in reduction of growth, yield, and quality of plants. Therefore, the over expression of genes encoding the biosynthetic enzymes may increase proline concentration in plant cells (Apse and Blumwald, 2002; Rabiei et al. 2011). On the other hand, oxidation reactions from choline to glycine betaine enhance plant resistance to salinity (Apse and Blumwald, 2002). Saline stress increases production of reactive oxygen species (ROS) including superoxide radicals $\left(\mathrm{O}_{2}{ }^{-}\right)$, hydrogen peroxide $\left(\mathrm{H}_{2} \mathrm{O}_{2}\right)$, and hydroxyl radicals $\left(\mathrm{OH}^{*}\right)$ which cause oxidative damage to different cellular components including membrane lipids, proteins, and nucleic acids (Hasanuzzaman et al., 2020). Plants use low molecular mass antioxidants such as ascorbic acid, superoxide dismutase (SOD), catalases (CAT), ascorbate peroxidases (APX), glutathione S-transferases (GST) and glutathione peroxidases (GPX) to scavenge ROS (Apse and Blumwald, 2002). Several mechanisms have been developed in plants under salt stress, one of which is the control of ion movement across tonoplasts to maintain a low $\mathrm{Na}^{+}$concentration in the cytoplasm (Brini and Masmoudi, 2012). Apse and Blumwald (2002) showed that plants could use several strategies to keep a high $\mathrm{K}^{+} / \mathrm{Na}^{+}$ratio in the cytosol to control the entry of $\mathrm{Na}^{+}$ions into and out of cells.

Polyploidy has been used in horticulture as a breeding tool to improve morphological, physiological, and physio-biochemical characteristics (Kermani et al. 2003,
Talebi et al. 2017). Some polyploids are tolerant to environmental stresses such as drought (Li et al. 2009), heat (Zhang et al. 2010), nutrient-poor soils (Kolar et al. 2014), and salinity (Mouhaya et al. 2010, Podda et al. 2013). This increased tolerance may be related to duplicate gene expression or simply associated with evolutionary processes. Meanwhile, few studies have specifically reported the relationship between ploidy level and abiotic tolerance in plants (Podda et al. 2013). Polyploidy plants had enabled better adaptation to some detrimental environmental conditions (Parisod et al., 2010) and enhanced tolerance to a range of abiotic stresses and biotic, souch as soil salinity (Chao et al., 2013). Polyploidy improved resistance to salt stress in rice (Tu et al., 2014), and citrus tetraploid genotypes (Mouhaya et al., 2010). Salt resistance in polyploidy plants was related to reduced sensitivity of plasma membrane $\mathrm{K}^{+}$- permeable channels in the meristem root zone and increased sensitivity of $\mathrm{Ca}^{2+}$-permeable channels in the elongation and mature root zones to $\mathrm{H} 2 \mathrm{O} 2$ (Liu et al., 2019).

Omami et al. (2006) reported that CAT is one of the major antioxidant enzymes which breaks down $\mathrm{H}_{2} \mathrm{O}_{2}$ to oxygen and water. Chao et al. (2013) reported that autopolyploidy induces resistance to salinity and may represent an adaptive outcome of the enhanced $\mathrm{K}^{+}$ accumulation of plants with higher ploidy. Bagheri and Mansouri (2014) found that polyploidy raised protein and sugar content under saline conditions. In another study, Munns (2002) suggested that the soil salt reduced water absorption and growth rate which could be due to loss of cellular turgor pressure and hormonal signals produced by the roots. When the amounts of salt rise to toxic levels in the plant cell, it is transported to leaves, which results in reduction of the photosynthetic leaf area and premature leaf senescence (Munns, 2002). In salttolerant plants, there is a low rate of $\mathrm{Na}^{+}$and $\mathrm{Cl}^{-}$transport to leaves where these ions are sorted in vacuoles in a way to prevent their build-up in cytoplasm, cell walls, and avoid salt toxicity (Greenway and Munns, 1980).

Aromatic plants that are salt stress tolerant should also maintain their growth and secondary metabolite production (Aziz et al. 2008; Ahmadi et al. 2013). Tabatabaie et al. (2007) showed that abiotic stress changed the quantity and quality of essential oil and thus reduced the market value of the Mentha piperita plants. Aziz et al. (2008) reported that essential oil yields of Peppermint (Mentha piperita L.), Pennyroyal (Mentha pulegium L.), and Apple mint (Mentha suaveolens Ehrh.) diminished under salt stress, compared with controls.

Currently, there is no information available regarding the effects of salt stress on induced polyploid anise hyssop plants compared with diploid parents. Accord- 
ingly, the purpose of this study was to compare the effect of salt stress on tetraploid and diploid plants by measuring growth rate, antioxidant enzyme activity, and essential oil content of this plant.

\section{MATERIALS AND METHODS}

The tetraploid $(2 \mathrm{n}=4 \mathrm{x}=36)$ and diploid $(2 \mathrm{n}=2 \mathrm{x}=18)$ explants of anise hyssop (Agastache foeniculum [Pursh.] Kuntze) that were used in this study were obtained from our previous study (Talebi et al. 2017). These plants were grown under greenhouse conditions $(16 / 8 \mathrm{~h}$ light/dark cycle, $21^{\circ} \mathrm{C}$ and $15^{\circ} \mathrm{C}$ day/night temperature and $60 \%$ humidity). The tetraploid and diploid explants were cultured on an

Murashige and Skoog medium medium containing $0.6 \mathrm{mg} / \mathrm{l}$ 6-benzylaminopurine (BAP) and $0.2 \mathrm{mg} / \mathrm{l}$ 1-naphthaleneacetic acid (NAA) and sub-cultured every four weeks (Fig. 1). The cultures were incubated under controlled conditions of temperature $\left(25 \pm 2^{\circ} \mathrm{C}\right)$, light (2000- 2500 lux for $16 \mathrm{~h} / \mathrm{d}$ provided by fluorescent tubes), and $60-70 \%$ humidity.

Adaptation of micropropagated plantlets was carried out in pots filled with sand and vermiculite (1:1, v:v) in a greenhouse. Initially, all plants were irrigated with a nutrient solution with half strength Hoagland's for 4 weeks and then irrigated every 3 days with full-strength Hoagland's solution containing salt $(\mathrm{NaCl})$ at $0,50,100$, and $150 \mathrm{mM}$ (Hoagland and Arnon 1950). The cultures were then incubated under a photoperiod of $16 \mathrm{hr}$ light and $8 \mathrm{hr}$ dark, light intensity of 2000-2500 lux, and at a temperature of $21^{\circ} \mathrm{C}$ day and $15^{\circ} \mathrm{C}$ night and $60 \%$

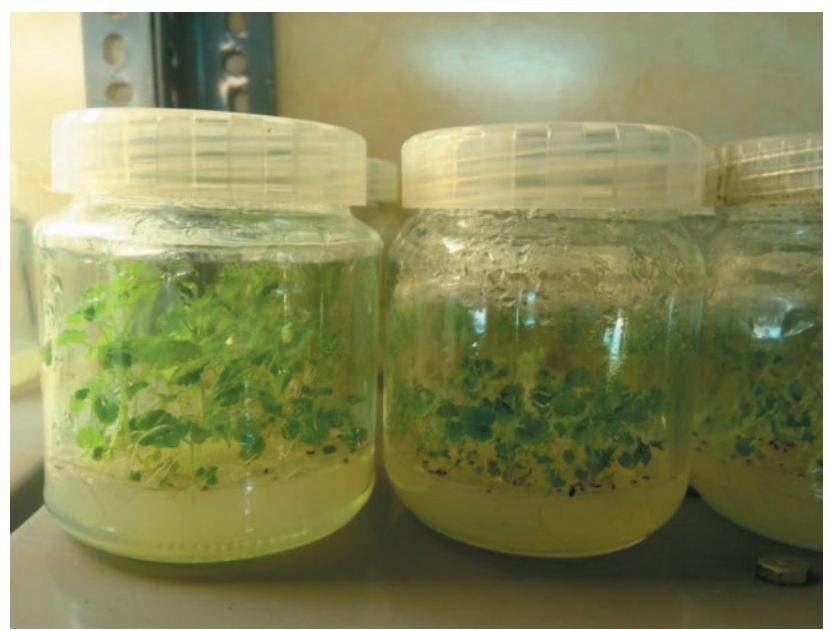

Figure 1. Micropropagation of tetraploid and diploid plants of anise hyssop. humidity. Morphological traits such as survival percentage and plant growth (leaf and shoot number, stem length) were measured.

Essential oil content was measured after three months. This content was determined using hydro-distillation by placing the aerial parts of dried plants $(10 \mathrm{~g})$ in a modified Clevenger apparatus for 3 hours (Ozturk et al. 2004) whereafter the essential oil content (w/w \%) was calculated. The composition of essential oil was analyzed by GC-MS (Agilent Technologies 5977A GC/MSD System, USA) analysis, using a fused silica capillary HP-5 column $(30 \mathrm{~m} \times 0.32 \mathrm{~mm}$ i.d.; film thickness 0.25 $\mu \mathrm{m}$ with an Agilent gas chromatograph series 7890A equipped with a flame ionization detector (FID). The injector and detector temperatures were kept at $250^{\circ} \mathrm{C}$ and $280^{\circ} \mathrm{C}$, respectively. Nitrogen was used as carrier gas at a flow rate of $1 \mathrm{ml} / \mathrm{min}$; oven temperature program was $60210^{\circ} \mathrm{C}$ at the rate of $4^{\circ} \mathrm{C}$.min, which was then programmed to $240^{\circ} \mathrm{C}$ at the rate of $20^{\circ} \mathrm{C}$.min, and finally, held isothermally for $8.5 \mathrm{~min}$. The split ratio was 1:50 and the GC-MS analysis was carried out by Agilent gas chromatograph equipped with fused silica capillary HP5MS column $(30 \mathrm{~m} \times 0.25 \mathrm{~mm}$ i.d.; film thickness 0.25 $\mu \mathrm{m})$ coupled with 5975C mass spectrometer. Helium was used as carrier gas with an ionization voltage of $70 \mathrm{eV}$. Ion source and interface temperatures were $230^{\circ} \mathrm{C}$ and $280^{\circ} \mathrm{C}$, respectively. Finally, the mass ranged from 45 to $550 \mathrm{amu}$ (atomic mass unit). The activity of antioxidant enzymes such as CAT and POD was measured according to the method of Chance and Maehly (1955). Experiments were analyzed in a factorial design based on a completely randomized design. Analysis of variance was performed and comparisons of means were conducted using Duncan's multiple range test (DMRT) at the 0.01 or 0.05 levels of probability. All analyses were performed using SAS and MSTATC software.

\section{RESULTS}

It was observed that the survival percentage of diploid and tetraploid plants decreased with elevation of $\mathrm{NaCl}$ concentrations. The diploids survived at $100 \mathrm{mM}$ $\mathrm{NaCl}$, while tetraploids were able to survive at a higher salt concentration of $150 \mathrm{mM}$ (Fig. 2, 3). Diploid plants did not tolerate $150 \mathrm{mM} \mathrm{NaCl}$ and died under these conditions, while $21 \%$ tetraploid plants survived at $150 \mathrm{mM}$ $\mathrm{NaCl}$.

The results revealed that stem length, leaf and shoot number significantly declined in tetraploid and diploid plantlets of anise hyssop under salt stress. In diploids and tetraploids, the highest stem length and number 


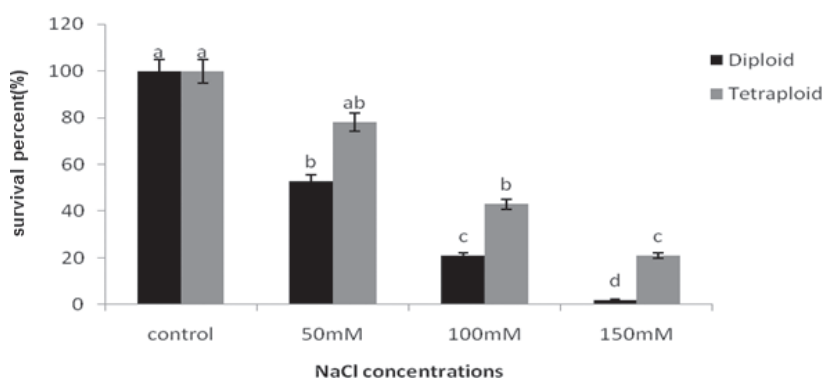

Figure 2. Effect of salt stress on survival percent in diploid and tetraploid plants.

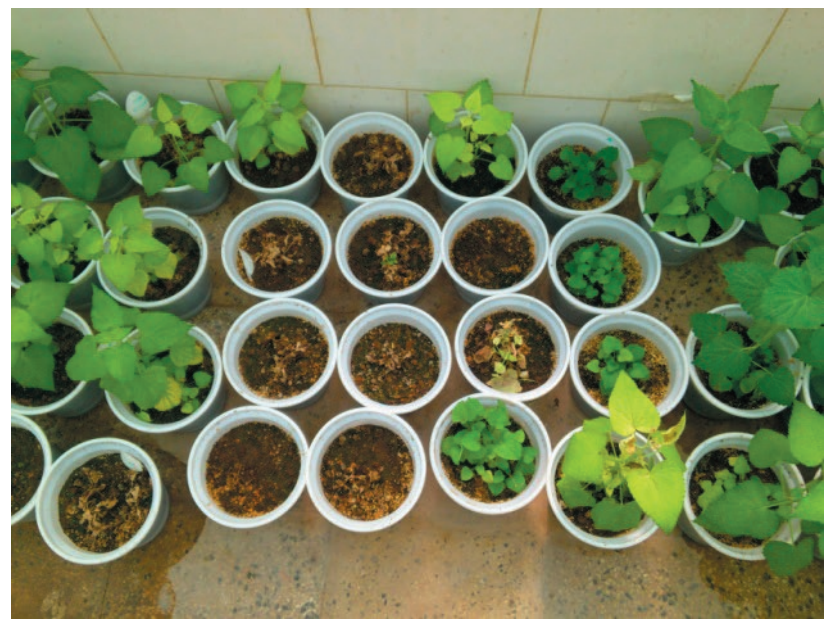

Figure 3. Effect of salt stress on survival of diploid and tetraploid plants.

of leaves and shoots was observed in the control, while the lowest stem length and leaf and shoot number was detected at $150 \mathrm{mM} \mathrm{NaCl}$ (Figs. 4, 5, 6).

The results indicated that CAT activity was enhanced at 50 and $100 \mathrm{mM} \mathrm{NaCl}$ treatments in diploids and tetraploids of Anise hyssop. Although the CAT activity decreased at $150 \mathrm{mM} \mathrm{NaCl}$ in both diploids and tetraploids, it remained higher in $150 \mathrm{mM} \mathrm{NaCl}$ treatment compared with the control (Table 1). Fig 8? illustrates that the plants treated with $100 \mathrm{mM} \mathrm{NaCl}$ had the highest POD activity. However, the activity of antioxidant enzymes was higher in the tetraploid plants (Table 1).

The essential oil content extracted from the diploid and tetraploid plants is displayed in Fig. 7. The results indicated that salinity reduced the essential oil content in diploid and tetraploid plants as compared with essential oil produced in control plants. The maximum essential oil percentages in diploid (1.37\%) and tetraploid $(2.82 \%)$ plants were obtained from control plants. The minimum essential oil content was observed in $150 \mathrm{mM}$

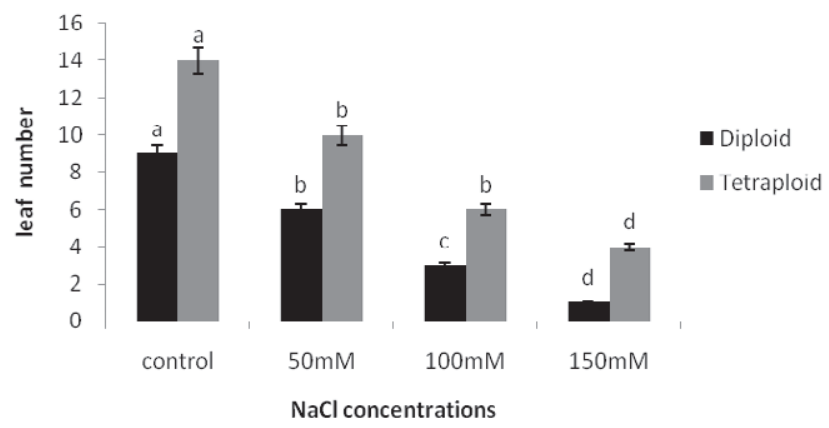

Figure 4. Effect of salt stress on leaf number in diploid and tetraploid plants.

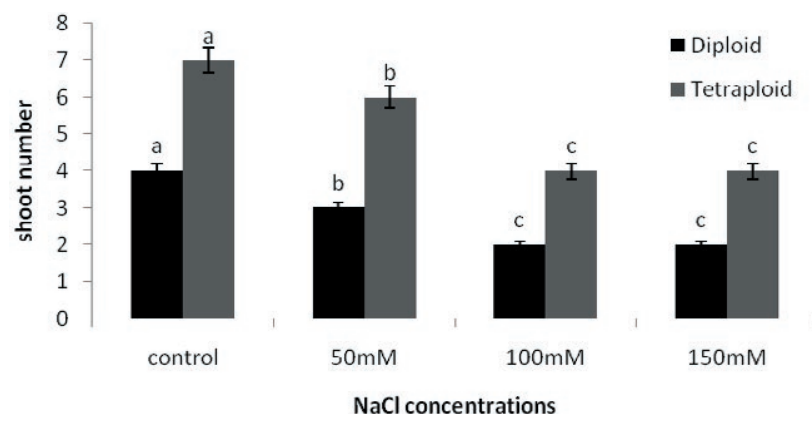

Figure 5. Effect of salt stress on shoot number in diploid and tetraploid plants.

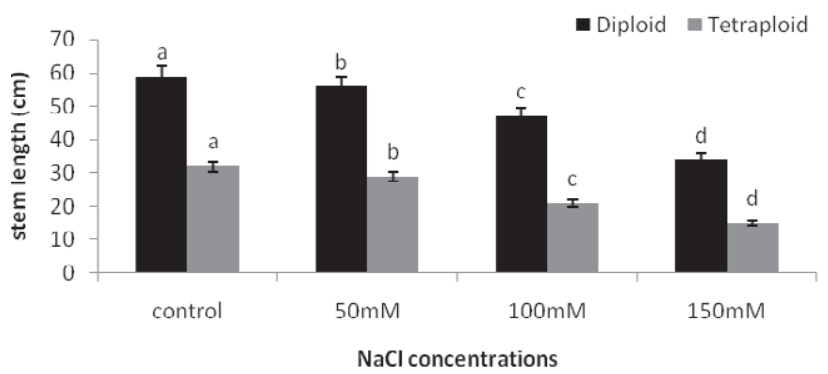

Figure 6. Effect of salt stress on stem length in diploid and tetraploid plants.

$\mathrm{NaCl}$ in diploid $(0.71 \%)$ and tetraploid (1.97\%) plants. The reductions in essential oil content were greater in diploids than in tetraploids under salt conditions.

The results of components identified through gas chromatography (GC/MS) in diploid and tetraploid plants are reported in Table 2. In tetraploid plants, with an increase in salt stress, the percentage of methyl chavicol, anisaldehyde, and $\beta$-caryophyllene rose, while the percentage of $\alpha$-Thujene, Terpinene, and Germacrene D did not change. However, several other constituents decreased at the maximum salt concentration tested. 
Table 1. Influence of different concentrations of $\mathrm{NaCl}$ on selected antioxidant enzyme activity. Means with the same letters in each column are not significantly different at $\mathrm{p}<0.01 \%$.

\begin{tabular}{ccccc}
\hline \multicolumn{3}{c}{$\begin{array}{c}\text { POD activity } \\
\left(\mu \mathrm{mol} \mathrm{min} \mathrm{mg}^{-1} \text { protein }\right)\end{array}$} & $\begin{array}{c}\text { CAT activity } \\
\left(\mu \mathrm{mol} \mathrm{min} \mathrm{mg}^{-1} \text { protein }\right)\end{array}$ \\
\hline $\begin{array}{c}\text { Tetraploid } \\
(\%)\end{array}$ & $\begin{array}{c}\text { Diploid } \\
(\%)\end{array}$ & $\begin{array}{c}\text { Tetraploid } \\
(\%)\end{array}$ & $\begin{array}{c}\text { Diploid } \\
(\%)\end{array}$ & Treatment \\
\hline $1.17 \mathrm{~d}$ & $0.67 \mathrm{~d}$ & $2.31 \mathrm{~d}$ & $1.07 \mathrm{~d}$ & Control \\
$1.33 \mathrm{~b}$ & $0.84 \mathrm{~b}$ & $2.43 \mathrm{~b}$ & $1.24 \mathrm{~b}$ & $50 \mathrm{mM}$ \\
$1.62 \mathrm{a}$ & $1.16 \mathrm{a}$ & $2.50 \mathrm{a}$ & $1.34 \mathrm{a}$ & $100 \mathrm{mM}$ \\
$1.21 \mathrm{c}$ & $0.71 \mathrm{c}$ & $2.37 \mathrm{c}$ & $1.14 \mathrm{c}$ & $150 \mathrm{mM}$ \\
\hline
\end{tabular}

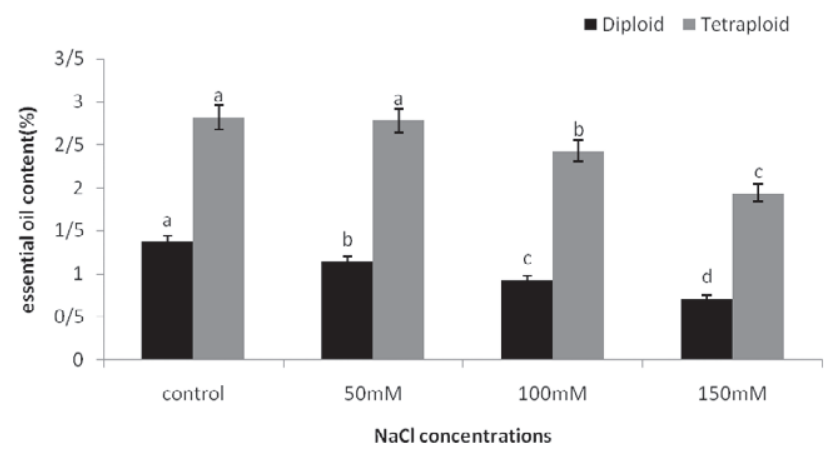

Figure 7. Effect of salt stress on essential oil content in diploid and tetraploid plants.

Data revealed that the percentage of all chemical constituents of essential oil in the diploid plants decreased with elevated $\mathrm{NaCl}$ concentration. In contrast, the changes in the essential oil constituent levels in the tetraploid plants were relatively lower than in diploid plants under the salt stress conditions.

\section{DISCUSSION}

According to the results of this study, salt stress reduced survival percentage and plant growth in tetraploid and diploid plants. The main reason for this reduction may be attributed to suppression of growth due to changes in developmental pathways under saline conditions. Salt stress reduced leaf growth and leaves exhibited wilting and chlorosis in diploid plants (Meng et al. 2011, Wang et al. 2013). Studies of Munns (2002) showed that plants treated under saline conditions had decreased water availability as well as sodium chloride toxicity. Munns (2002) reported that salt-induced drought stress decreased the ability of the plant to absorb water and nutrients from the soil. The ability of plant cells to prevent $\mathrm{Na}^{+}$transport into the growing tissues is critically important for maintaining metabolic processes during cell growth against the toxic effects of $\mathrm{Na}^{+}$(Khorasaninejad et al. 2010). Khorasaninejad et al. (2010) reported that reduction in dry weight under salinity stress may be related to inhibition of hydrolysis of reserved foods and their translocation to the growing shoots. Similar decreases in growth parameters under salt stress were found in Salvia officinalis (Ben Taarit et al., 2009), thyme (Ezz El-Din et al. 2009), and basil (Said-Al Ahl and Mahmoud, 2010).

In this study, the highest activity of antioxidant enzymes was observed in the plants treated with 100 $\mathrm{mM} \mathrm{NaCl}$. Increasing salinity beyond $100 \mathrm{mM} \mathrm{NaCl}$ significantly decreased the activity of antioxidant enzymes. Under salt stress conditions, reactive oxygen species (ROS) increase in chloroplasts (Meng et al. 2016). Generally, salt stress results in an increased accumulation of ROS, such as $\mathrm{H}_{2} \mathrm{O}_{2}$, which may act as a signal molecule during stress conditions, which in turn induces gene expression encoding antioxidant enzymes (Breusegem et al. 2001). Tseng (2007) showed that salt stress tolerance in cabbage was enhanced with the production of cuprozincsuperoxide dismutase (Cu/Zn SOD) and catalase (CAT) in chloroplasts. The levels of plant hormones such as abscisic acid (ABA) increase with high salt concentrations. ABA plays an important role in the mechanism of salt tolerance (Omami et al. 2006). Chao et al. (2013) found that autopolyploid plants have greater tolerance to salinity compared with diploids, which could be related to the enhanced $\mathrm{K}^{+}$in the tetraploid plants. Meng et al. (2016) reported that salt stress facilitated increased $\mathrm{H}_{2} \mathrm{O}_{2}$ production, antioxidative enzymes, non-enzymatic antioxidants, and protein activity in tetraploid plants compared with diploid plants. On the other hand, gene expression and synthesis of plant hormones such as ABA grow under salt conditions (Riddle et al. 2010). Tu et al. (2014) found that tetraploid rice showed less root growth inhibition, accumulated a higher proline content and lower malondialdehyde (MDA) content, and exhibited a higher frequency of normal epidermal cells than diploid rice did under salt conditions. The response of salt-tolerant organisms to salinity stress involves synthesis and accumulation of osmo-protective compounds, which are small, non-toxic compounds and can stabilize proteins, cellular structures and increase the osmotic pressure of the cell (Yancey et al. 1982). The high levels of proline and glycine betaine were correlated with improved tolerance to salinity (Apse and Blumwald, 2002). Similar results were observed in Melissa officinalis (Ozturk et al. 2004), Majorana hortensis (Shalan et al. 2006), Thymus vulgaris (Najafian et al. 2009), and Mentha pulegium (Queslati et al. 2010). 
Table 2. The effect of salt stress on essential oil composition in diploid and tetraploid plants. ${ }^{* *}$ Means followed by the same letter in each row are not significantly different by LSD test $(\mathrm{P}<0.05)$.

\begin{tabular}{|c|c|c|c|c|c|c|c|c|}
\hline \multirow{2}{*}{ Compounds } & \multicolumn{4}{|c|}{$\begin{array}{c}\text { Diploid } \\
\mathrm{NaCl}(\mathrm{mM})\end{array}$} & \multicolumn{4}{|c|}{$\begin{array}{l}\text { Tetraploid } \\
\mathrm{NaCl}(\mathrm{mM})\end{array}$} \\
\hline & control & $50 \mathrm{mM}$ & $100 \mathrm{mM}$ & $150 \mathrm{mM}$ & control & $50 \mathrm{mM}$ & $100 \mathrm{mM}$ & $150 \mathrm{mM}$ \\
\hline a-Thujene & $0.52^{\mathrm{a}}$ & $0.51^{\mathrm{b}}$ & $0.46^{\mathrm{c}}$ & $0.44^{\mathrm{d}}$ & $0.64^{\mathrm{a}}$ & $0.61^{\mathrm{c}}$ & $0.63^{b}$ & $0.64^{\mathrm{a}}$ \\
\hline$\alpha$-Pinene & $0.61^{\mathrm{a}}$ & $0.59^{\mathrm{b}}$ & $0.54^{\mathrm{c}}$ & $0.52^{\mathrm{d}}$ & $0.42^{\mathrm{a}}$ & $0.41^{\mathrm{b}}$ & $0.34^{\mathrm{c}}$ & $0.27^{\mathrm{d}}$ \\
\hline Camphene & $0.52^{\mathrm{a}}$ & $0.50^{\mathrm{b}}$ & $0.42^{\mathrm{c}}$ & $0.39^{\mathrm{d}}$ & $0.41^{\mathrm{a}}$ & $0.41^{\mathrm{a}}$ & $0.32^{\mathrm{b}}$ & $0.22^{\mathrm{c}}$ \\
\hline 1 -Octen-3-ol & $0.28^{\mathrm{a}}$ & $0.17^{\mathbf{b}}$ & $0.11^{\mathrm{c}}$ & $0.09^{d}$ & $0.35^{\mathrm{a}}$ & $0.31^{\mathbf{b}}$ & $0.23^{\mathrm{c}}$ & $0.22^{\mathrm{d}}$ \\
\hline 3-Octanone & $0.37^{\mathrm{a}}$ & $0.31^{\mathrm{b}}$ & $0.22^{\mathrm{c}}$ & $0.16^{\mathrm{d}}$ & $0.14^{\mathrm{a}}$ & $0.09^{b}$ & $0.00^{c}$ & $0.00^{c}$ \\
\hline Sabinene & $0.18^{\mathrm{a}}$ & $0.14^{\mathrm{b}}$ & $0.7^{\mathrm{c}}$ & $0.00^{\mathrm{d}}$ & $0.30^{\mathrm{a}}$ & $0.23^{\mathrm{b}}$ & $0.11^{\mathrm{c}}$ & $0.02^{\mathrm{d}}$ \\
\hline$\beta$-Pinene & $0.52^{\mathrm{a}}$ & $0.44^{\mathrm{b}}$ & $0.39^{c}$ & $0.21^{\mathrm{d}}$ & $0.34^{\mathrm{a}}$ & $0.26^{\mathrm{b}}$ & $0.16^{\mathrm{c}}$ & $0.06^{\mathrm{d}}$ \\
\hline 3-Octanol & $0.04^{\mathrm{a}}$ & $0.00^{\mathrm{b}}$ & $0.00^{\mathrm{b}}$ & $0.00^{\mathbf{b}}$ & $0.10^{\mathrm{a}}$ & $0.05^{\mathrm{b}}$ & $0.00^{c}$ & $0.00^{\mathrm{c}}$ \\
\hline myrcene & $0.04^{\mathrm{a}}$ & $0.00^{\mathbf{b}}$ & $0.00^{\mathrm{b}}$ & $0.00^{\mathrm{b}}$ & $0.06^{\mathrm{a}}$ & $0.00^{\mathrm{b}}$ & $0.00^{c}$ & $0.00^{c}$ \\
\hline p-Cymene & $0.63^{\mathrm{a}}$ & $0.54^{\mathrm{b}}$ & $0.49^{c}$ & $0.36^{\mathrm{d}}$ & $0.84^{\mathrm{a}}$ & $0.84^{\mathrm{a}}$ & $0.75^{\mathrm{b}}$ & $0.73^{c}$ \\
\hline 1,8 Cineole & $3.24^{\mathrm{a}}$ & $3.23^{\mathrm{b}}$ & $3.18^{\mathrm{c}}$ & $3.13^{\mathrm{d}}$ & $3.05^{\mathrm{a}}$ & $2.98^{b}$ & $2.87^{\mathrm{c}}$ & $2.86^{\mathrm{d}}$ \\
\hline Limonene & $2.69^{\mathrm{a}}$ & $2.61^{b}$ & $2.56^{\mathrm{c}}$ & $2.53^{\mathrm{d}}$ & $3.02^{\mathrm{a}}$ & $2.92^{\mathrm{b}}$ & $2.94^{\mathrm{c}}$ & $2.93^{d}$ \\
\hline$\gamma$-Terpinene & $0.37^{\mathrm{a}}$ & $0.29^{\mathrm{b}}$ & $0.15^{\mathrm{c}}$ & $0.07^{\mathrm{d}}$ & $0.32^{\mathrm{a}}$ & $0.30^{\mathbf{b}}$ & $0.29^{c}$ & $0.32^{\mathrm{d}}$ \\
\hline Trans-sabinene hydrate & $0.04^{\mathrm{a}}$ & $0.00^{\mathbf{b}}$ & $0.00^{\mathrm{b}}$ & $0.00^{\mathbf{b}}$ & $0.04^{\mathrm{a}}$ & $0.00^{\mathbf{b}}$ & $0.00^{\mathrm{b}}$ & $0.00^{\mathbf{b}}$ \\
\hline Cis-linalool oxide & $0.08^{\mathrm{a}}$ & $0.03^{\mathrm{b}}$ & $0.00^{c}$ & $0.00^{\mathfrak{c}}$ & $0.05^{\mathrm{a}}$ & $0.00^{\mathbf{b}}$ & $0.00^{\mathbf{b}}$ & $0.00^{\mathrm{b}}$ \\
\hline Trans-linalool oxide & $0.05^{\mathrm{a}}$ & $0.00^{\mathbf{b}}$ & $0.00^{\mathrm{b}}$ & $0.00^{\mathbf{b}}$ & $0.06^{\mathrm{a}}$ & $0.00^{\mathbf{b}}$ & $0.00^{\mathbf{b}}$ & $0.00^{\mathbf{b}}$ \\
\hline Linalool & $0.55^{\mathrm{a}}$ & $0.46^{\mathrm{b}}$ & $0.43^{\mathrm{c}}$ & $0.39^{\mathrm{d}}$ & $0.61^{\mathrm{a}}$ & $0.53^{\mathrm{b}}$ & $0.47^{\mathrm{c}}$ & $0.42^{\mathrm{d}}$ \\
\hline 1 -Octen-3-yl acetate & $0.28^{\mathrm{a}}$ & $0.19^{b}$ & $0.12^{\mathrm{c}}$ & $0.09^{d}$ & $0.37^{\mathrm{a}}$ & $0.31^{\mathbf{b}}$ & $0.27^{\mathfrak{c}}$ & $0.26^{\mathrm{d}}$ \\
\hline a-Campholenal & $0.02^{\mathrm{a}}$ & $0.00^{\mathbf{b}}$ & $0.00^{\mathbf{b}}$ & $0.00^{\mathbf{b}}$ & $0.02^{\mathrm{a}}$ & $0.00^{\mathbf{b}}$ & $0.00^{\mathrm{b}}$ & $0.00^{\mathbf{b}}$ \\
\hline Camphor & $0.04^{\mathrm{a}}$ & $0.00^{\mathbf{b}}$ & $0.00^{\mathbf{b}}$ & $0.00^{\mathbf{b}}$ & $0.07^{\mathrm{a}}$ & $0.03^{\mathbf{b}}$ & $0.00^{c}$ & $0.00^{\mathfrak{c}}$ \\
\hline Trans-pinocarveol & $0.27^{\mathrm{a}}$ & $0.16^{\mathrm{b}}$ & $0.08^{c}$ & $0.00^{\mathrm{d}}$ & $0.30^{\mathrm{a}}$ & $0.26^{\mathbf{b}}$ & $0.18^{\mathrm{c}}$ & $0.09^{\mathrm{d}}$ \\
\hline Trans-verbenol & $0.04^{\mathrm{a}}$ & $0.00^{\mathrm{b}}$ & $0.00^{\mathrm{b}}$ & $0.00^{\mathbf{b}}$ & $0.02^{\mathrm{a}}$ & $0.00^{\mathrm{b}}$ & $0.00^{\mathbf{b}}$ & $0.00^{\mathrm{b}}$ \\
\hline Pinocawone & $0.03^{\mathrm{a}}$ & $0.00^{\mathrm{b}}$ & $0.00^{\mathrm{b}}$ & $0.00^{\mathbf{b}}$ & $0.03^{\mathrm{a}}$ & $0.00^{\mathrm{b}}$ & $0.00^{\mathbf{b}}$ & $0.00^{\mathrm{b}}$ \\
\hline Borneol & $0.52^{\mathrm{a}}$ & $0.47^{\mathrm{b}}$ & $0.42^{\mathrm{c}}$ & $0.39^{\mathrm{d}}$ & $0.28^{\mathrm{a}}$ & $0.22^{\mathrm{b}}$ & $0.19^{c}$ & $0.11^{\mathrm{d}}$ \\
\hline Terpinen-4-ol & $0.02^{\mathrm{a}}$ & $0.00^{\mathrm{b}}$ & $0.00^{\mathbf{b}}$ & $0.00^{\mathbf{b}}$ & $0.05^{\mathrm{a}}$ & $0.00^{\mathrm{b}}$ & $0.00^{\mathbf{b}}$ & $0.00^{\mathbf{b}}$ \\
\hline Methyl chavicol & $78.77^{\mathrm{a}}$ & $78.73^{b}$ & $78.68^{c}$ & $78.61^{d}$ & $81.11^{\mathrm{d}}$ & $81.13^{\mathrm{a}}$ & $81.13^{\mathbf{b}}$ & $81.15^{\mathrm{a}}$ \\
\hline Piperitone & $0.35^{\mathrm{a}}$ & $0.26^{\mathrm{b}}$ & $0.18^{\mathfrak{c}}$ & $0.03^{\mathrm{d}}$ & $0.20^{\mathrm{a}}$ & $0.14^{\mathrm{b}}$ & $0.09^{c}$ & $0.00^{\mathrm{d}}$ \\
\hline Anisaldehyde & $0.68^{\mathrm{a}}$ & $0.54^{\mathrm{b}}$ & $0.43^{\mathrm{c}}$ & $0.34^{\mathrm{d}}$ & $0.81^{\mathbf{b}}$ & $0.80^{\mathrm{c}}$ & $0.82^{\mathrm{ba}}$ & $0.82^{\mathrm{a}}$ \\
\hline Bornylacetate & $0.54^{\mathrm{a}}$ & $0.47^{\mathrm{b}}$ & $0.31^{\mathrm{c}}$ & $0.28^{\mathrm{d}}$ & $0.42^{\mathrm{a}}$ & $0.37^{\mathbf{b}}$ & $0.33^{\mathrm{c}}$ & $0.26^{\mathrm{d}}$ \\
\hline$\beta$-Bourbonene & $0.58^{\mathrm{a}}$ & $0.56^{\mathrm{b}}$ & $0.51^{\mathrm{c}}$ & $0.45^{\mathrm{d}}$ & $0.44^{\mathrm{a}}$ & $0.40^{\mathrm{b}}$ & $0.39^{c}$ & $0.37^{\mathrm{d}}$ \\
\hline$\beta$-Caryophyllene & $0.72^{\mathrm{a}}$ & $0.65^{\mathrm{b}}$ & $0.41^{\mathrm{c}}$ & $0.35^{\mathrm{d}}$ & $0.61^{\mathrm{c}}$ & $0.56^{\mathrm{d}}$ & $0.63^{b}$ & $0.65^{\mathrm{a}}$ \\
\hline (E)-a-Bergamotene & $0.05^{\mathrm{a}}$ & $0.00^{\mathbf{b}}$ & $0.00^{\mathbf{b}}$ & $0.00^{\mathbf{b}}$ & $0.03^{\mathrm{a}}$ & $0.00^{\mathbf{b}}$ & $0.00^{\mathbf{b}}$ & $0.00^{\mathbf{b}}$ \\
\hline a-Humulene & $0.04^{\mathrm{a}}$ & $0.00^{\mathbf{b}}$ & $0.00^{\mathbf{b}}$ & $0.00^{\mathbf{b}}$ & $0.02^{\mathrm{a}}$ & $0.00^{\mathbf{b}}$ & $0.00^{\mathbf{b}}$ & $0.00^{\mathbf{b}}$ \\
\hline Germacrene D & $0.24^{\mathrm{a}}$ & $0.17^{\mathbf{b}}$ & $0.00^{c}$ & $0.00^{\mathfrak{c}}$ & $0.30^{\mathrm{a}}$ & $0.30^{\mathrm{a}}$ & $0.29^{\mathbf{b}}$ & $0.30^{\mathrm{a}}$ \\
\hline$\beta$-Selinene & $0.02^{\mathrm{a}}$ & $0.00^{\mathbf{b}}$ & $0.00^{\mathbf{b}}$ & $0.00^{\mathbf{b}}$ & $0.03^{\mathrm{a}}$ & $0.00^{\mathbf{b}}$ & $0.00^{\mathbf{b}}$ & $0.00^{\mathbf{b}}$ \\
\hline Valencene & $0.02^{\mathrm{a}}$ & $0.00^{\mathbf{b}}$ & $0.00^{\mathbf{b}}$ & $0.00^{\mathbf{b}}$ & $0.03^{\mathrm{a}}$ & $0.00^{\mathbf{b}}$ & $0.00^{\mathbf{b}}$ & $0.00^{\mathbf{b}}$ \\
\hline Bicyclogermacrene & $0.20^{\mathrm{a}}$ & $0.13^{\mathrm{b}}$ & $0.00^{c}$ & $0.00^{c}$ & $0.21^{\mathrm{a}}$ & $0.17^{\mathbf{b}}$ & $0.08^{\mathfrak{c}}$ & $0.00^{\mathrm{d}}$ \\
\hline$\beta$-Bisabolene & $0.02^{\mathrm{a}}$ & $0.00^{\mathbf{b}}$ & $0.00^{\mathrm{b}}$ & $0.00^{\mathbf{b}}$ & $0.01^{\mathrm{a}}$ & $0.00^{\mathrm{b}}$ & $0.00^{\mathrm{b}}$ & $0.00^{\mathbf{b}}$ \\
\hline$\gamma$-Cadinene & $0.04^{\mathrm{a}}$ & $0.00^{\mathbf{b}}$ & $0.00^{\mathrm{b}}$ & $0.00^{\mathbf{b}}$ & $0.02^{\mathrm{a}}$ & $0.00^{\mathbf{b}}$ & $0.00^{\mathbf{b}}$ & $0.00^{\mathbf{b}}$ \\
\hline$\delta$-Cadinene & $0.04^{\mathrm{a}}$ & $0.00^{\mathrm{b}}$ & $0.00^{\mathbf{b}}$ & $0.00^{\mathrm{b}}$ & $0.06^{\mathrm{a}}$ & $0.00^{\mathrm{b}}$ & $0.00^{\mathbf{b}}$ & $0.00^{\mathbf{b}}$ \\
\hline Spathulenol & $0.33^{\mathrm{a}}$ & $0.26^{\mathrm{b}}$ & $0.23^{\mathrm{c}}$ & $0.10^{\mathrm{d}}$ & $0.45^{\mathrm{a}}$ & $0.39^{\mathbf{b}}$ & $0.36^{\mathfrak{c}}$ & $0.27^{\mathrm{d}}$ \\
\hline Caryophyllene oxide & $0.30^{\mathrm{a}}$ & $0.33^{\mathrm{b}}$ & $0.25^{\mathrm{c}}$ & $0.07^{\mathrm{d}}$ & $0.48^{\mathrm{a}}$ & $0.42^{\mathrm{b}}$ & $0.31^{\mathrm{c}}$ & $0.27^{\mathrm{d}}$ \\
\hline Globulol & $1.45^{\mathrm{a}}$ & $1.29^{\mathrm{b}}$ & $1.13^{\mathrm{c}}$ & $0.57^{\mathrm{d}}$ & $1.72^{\mathrm{a}}$ & $1.72^{\mathrm{a}}$ & $1.67^{\mathrm{b}}$ & $1.67^{\mathrm{b}}$ \\
\hline
\end{tabular}


In our study, salinity reduced the essential oil content in diploid and tetraploid plants compared with control plants. Data showed that treatment of tetraploid plants with different concentrations of $\mathrm{NaCl}$ had a different response in terms of essential oil composition and production. In the diploid plants, the percentage of all chemical constituents of essential oil decreased with elevation of $\mathrm{NaCl}$ concentration. Aziz et al. (2008) found that essential oil synthesis in peppermint was very sensitive to stress. Further, Olfa et al. (2009) reported that essential oil content in marjoram (Origanum majorana) was reduced consistently with rising salt concentration. Salinity stress requires additional energy for plant cells; therefore, the amount of carbon for growth and flower initiation and essential oil synthesis is reduced during stress (Cheesman 1988). Reductions in essential oil content could be due to decreases and changes in photosynthesis systems, essential oil biosynthesis and metabolic pathways (Aziz et al. 2008). However, Belaqziz et al. (2009) reported that oil content of Thymus maroccanus did not change with elevation of salt concentration.

The results of the present investigation demonstrated that anise hyssop is sensitive to salt stress. However, tetraploid plants were more resistant to salt stress than diploids. This was most probably due to the bigger cell size and fewer cells in the unit area in tetraploids compared with diploids (Comai, 2005). Thus, the responses of polyploid plants may differ in terms of morphological, physiological, cellular and biochemical aspects (Shafieizargar et al. 2013). Riddle et al. (2010) reported that polyploidy induction increased chromosome number, DNA content, gene expression, and enzyme activity per cell. In addition, according to our previous study, the polyploid plants of anise hyssop had a larger stomata size and density, chloroplast number, morphological features (leaf length and width, distance between the nodes, leaf area, plant height, fresh and dry weight, and spikes length), and physio-biochemical characteristics (net photosynthesis, protein content, catalase and peroxidase activity) (Talebi et al. 2017). Thus, tetraploid plants could naturally tolerate salt stress better than diploid plants. According to Zhang et al. (2015), the response of the autotetraploid apple seedlings to salt stress was better than that of the diploid. Other reports have also suggested that polyploidy induction is an efficient way to increase abiotic stress tolerance in Spathiphyllum wallisii (Van Laere et al. 2010), Dendranthema nankingense (Liu et al. 2011), Brassica rapa L. (Meng et al. 2011), and Nicotiana benthamiana (Deng et al. 2012).

\section{CONCLUSION}

According to the results obtained in the present study, salt stress reduced survival percentage, stem length, leaf and shoot number in tetraploid and diploid plants. The minimum growth rates were detected at $150 \mathrm{mM} \mathrm{NaCl}$ in both diploids and tetraploids. However, since tetraploid plants had higher rates of growth compared with diploids, they showed a higher percentage survival and growth compared with diploids under salt stress conditions. The highest activity of antioxidant enzymes for the two ploidy levels was observed in the plants treated with $100 \mathrm{mM} \mathrm{NaCl}$. Tetraploid plants were more resistant to salt stress than diploids. Increasing salt concentration caused a significant reduction in the essential oil content in both tetraploid and diploid plants. Nonetheless, tetraploid plants showed different responses under different salinity stress conditions when the percentage of essential oil composition was measured. In the diploid plants, the percentage of all chemical constituents of essential oil decreased with increasing $\mathrm{NaCl}$ concentration. The results of our work suggest that in Anise hyssop, tetraploid plants have a better protective mechanism than diploid plants against saline conditions.

\section{ACKNOWLEDGEMENTS}

The authors wish to extend their thanks and appreciation to Shiraz and Shahed Universities Research and Technology Councils for their financial and technical supports.

\section{REFERENCES}

Ahmadi T, Jafarkhani Kermani M, Mashayekhi K, Hasanloo T, Shariatpanahi ME. 2013. Comparing plant morphology, fertility and secondary metabolites in Rosa hybrida CV Iceberg and its chromosome-doubled progenies. Int Res J of App and Bas Sci 4:3840-3849.

Apse MP, Blumwald E. 2002. Engineering salt tolerance in plants. Plant biotech. 13:146-150.

Aziz EE, Al-Amier H, Craker LE. 2008. Influence of Salt Stress on Growth and Essential Oil Production in Peppermint, Pennyroyal, and Apple Mint. J Herbs Spices and Medi Plants 14(1-2):77-87. doi. 10.1080/10496470802341375

Bagheri M, Mansouri H. 2014. Effect of Induced Polyploidy on Some Biochemical Parameters in Cannabis sativa L. App Biochem and Biotech 175(5). DOI. 10.1007/s12010-014-1435-8 
Belaqziz R, bderrahmane A, Abbad A. 2009. Salt stress effects on germination, growth and essential oil content of an endemic thyme species in Morocco (Thymus Maroccanus Ball.). J App Sci Res 5(7):858-863.

Ben Taarit MK, Msaada K, Hosni M, Hammami M, Kchouk E, Marzouk B .2009. Plant growth, essential oil yield and composition of Sage (salvia officinalis L.) fruits cultivated under salt stress conditions. Ind Crops Prod 30:333-7.

Breusegem FV, Vranova E, Dat JF, Inzé D. 2001. The role of active oxygen species in plant signal transduction. Plant Sci 16:405-414.

Brini F, Masmoudi K. 2012. Ion Transporters and Abiotic Stress Tolerance in Plants. Inter Scho Rese Not. doi. org/10.5402/2012/927436.

Chance B, Maehly AC. 1955. Assay of catalases and peroxidase. Metho in Enzym 2:764-775.

Chao DY, Dilkes B, Luo H, Douglas A, Yakubova E, Lahner B, Salt DE. 2013. Polyploids Exhibit Higher Potassium Uptake and Salinity Tolerance in Arabidopsis. Sci 341:658-659.

Cheesman JM. 1988. Mechanisms of Salinity Tolerance in Plants. J Plant Physiol 87: 547-50.

Comai L. 2005. The advantages and disadvantages of being polyploid. Natu Gene 6:836-846.

Deng B, Du W, Liu C, Sun W, Tian S, Dong H. 2012. Antioxidant response to drought, cold and nutrient stress in two ploidy levels of tobacco plants: low resource requirement confers polytolerance in polyploids. Plant Gro Regu 66:37-47.

Ezz El-Din AA, Aziz EE, Hendawy SF, Omer EA. 2009. Response of Thymus vulgaris $\mathrm{L}$. to salt stress and alar (B9) in newly reclaimed soil. J Appl Sci Res 5:2165-70.

Greenway H, Munns R. 1980. Mechanisms of Salt Tolerance in Nonhalophytes. Ann Re Plant Phy 31:149190.

Hasanuzzaman M, Borhannuddin Bhuyan MHM, Zulfiqar F, Raza A, Mohsin SM, Al Mahmud J, Fujita M, Fotopoulos V. 2020. Reactive Oxygen Species and Antioxidant Defense in Plants under Abiotic Stress: Revisiting the Crucial Role of a Universal Defense Regulator. Antioxidants 9(8):681. doi.org/10.3390/ antiox9080681

Heidari F, Zehtab Salmasi S, Javanshir A, Aliari H, Dadpoor MR. 2008. The Effects of Application Microelements and Plant Density on Yield and Essential oil of Peppermint (Mentha piperita L.). Iran J Med Arom Plants 24:1-9.

Heydari M, Sharafi Y, Tabatabaei SJ, Hokmabadi H. 2020. How Pistachio Hybrid "P. Integerrima $\times$ P. Vera " grows and responses to $\mathrm{NaCl}$ salinity. Inter J Fruit Science. doi.org/10.1080/15538362.2020.1860864.
Hoagland DR, Arnon DI. 1950. The Water-Culture Method for Growing Plants without Soil. California Agricultural Experiment Station, Circular 347p.

Kermani MJ, Sarasan V, Roberts AV, Yokoya K, Wentworth J, Sieber VK. 2003. Oryzalin-induced chromosome doubling in Rosa and its effect on plant morphology and pollen viability. Theo Appl Gen 107:1195-1200.

Khorasaninejad S, Mousavi A, Soltanloo H, Hemmati K, Khalighi A. 2010. The Effect of Salinity Stress on Growth Parameters, Essential oil Yield and Constituent of Peppermint (Mentha piperita L.). Wor App Sci J 11(11): 1403-1407.

Kolar F, Dortová M, Lepš J, Pouzar M, Krejčovám A, Štech M. 2014. Serpentine ecotypic differentiation in a polyploid plant complex: shared tolerance to $\mathrm{Mg}$ and $\mathrm{Ni}$ stress among di- and tetraploid serpentine populations of Knautia arvensis (Dipsacaceae). Plant Soil 374:435-447.

Li WD, Biswas DK, Xu H, Xu CQ, Wang XZ, Liu JK, Jiang GM. 2009. Photosynthetic responses to chromosome doubling in relation to leaf anatomy in Lonicera japonica subjected to water stress. Plant Biol 36:783-792.

Liu S, Chen S, Chen Y, Guan Z, Yin D, Chen F. 2011. In vitro induced tetraploid of Dendranthema nankingense (Nakai) Txvel. Shows an improved level of abiotic stress tolerance. Sci Hort 127:411-419.

Liu Y, Yu Y, Sun J, Cao Q, Tang Z, Liu M, Xu T, Ma D, Li Z, Sun J. 2019. Root-zone-specific sensitivity of $\mathrm{K}+$ - and $\mathrm{Ca} 2+-$ permeable channels to $\mathrm{H} 2 \mathrm{O} 2$ determines ion homeostasis in salinized diploid and hexaploid Ipomoea trifida. J Expe Bot 70: 1389-1405.

Meng F, Luo Q, Wang Q, Zhang X, Qi Z, Lei X, Cao Y, Chow WS, Sun G, Xu F. 2016. Physiological and proteomic responses to salt stress in chloroplasts of diploid and tetraploid Black locust (Robinia pseudoacacia L.). Scien Rep 1-15.

Meng HB, Jiang SS, Hua SJ, Lin XY, Li YL, Guo WL, Jiang LX. 2011. Comparison between a tetraploid turnip and its diploid progenitor (Brassica rapa L.): The adaptation to salinity stress. Agri Sci China 10:363-375.

Mouhaya W, Allario T, Brumos J, Andres F, Froelicher Y, Luro F,Talon M, Ollitrault P, Morillon R. 2010. Sensitivity to high salinity intetraploid citrus seedlings increases with water availability and correlates with expression of candidate genes. Func Plant Bio 37:674-685.

Munns R. 2002. Comparative Physiology of Salt and Water Stress. Plant Cell and Envi 25(2):239-250. doi. 10.1046/j.0016-8025.2001.00808.x 
Najafian S, Khoshkhui M, Tavallali V, Saharkhiz MJ. 2009. Effect of salicylic acid and salinity in Thyme (thymus vulgaris L.): investigation on changes in gas exchange, water relations, and membrane stabilization and biomass accumulation. Aust J Basic Appl Sci 3:2620-6.

Olfa BR, Kaddour W, Aidi Wannes M, Lachaal Marzouk B. 2009. Salt Effects on the Growth, Mineral Nutrition, Essential oil Yield and Composition of Marjoram (Origanum majorana). Acta Phy Plant 10: 03744.

Omami EN, Hammes PS, Robbertse PJ. 2006. Differences in salinity tolerance for growth and water-use efficiency in some Amaranth (Amaranthus spp.) genotypes. New Zeal J Crop Hort Sci 34:11-22.

Ozturk A, Unlukara A, Ipekl A, Gurbuz B. 2004. Effect of salt stress and water deficit on plant growth and essential oil content of Lemon balm (melissa officinalis L.). Pak J Bot 36:787-92.

Parisod C, Holderegger R, Brochmann C. 2010. Evolutionary consequences of autopolyploidy. New Phyto186: 5-17.

Podda A, Checcucci G, Mouhaya W, Centeno D, Rofidal V, Del Carratore R, Luro F, Morillon R, Ollitrault P, Maserti BE. 2013. Salt-stress induced changes in the leaf proteome of diploid and tetraploid mandarins with contrasting $\mathrm{Na}+$ and $\mathrm{Cl}$-accumulation behaviour. Plant Phy 170:1101-1112.

Queslati S, Karray-Bouraoui N, Attia H, Rabhi M, Ksouri R, Lachaal M. 2010. Physiological and antioxidant responses of mentha pulegium (Pennyroyal) to salt stress. Acta Phys Plant 32:289-96.

Rabiei V, Es-haghi S, Aazami MA, Sharafi Y.2011. Combined effects of hot air and calcium chloride on quality and antioxidant enzymes activity in 'red delicious' apple fruits. J Med Plant Res 5(19):4954-4961.

Riddle NC, Jiang H, An L, Doerge RW, Birchler JA. 2010. Gene expression analysis at the intersection of ploidy and hybridity in Maize. Theor Appl Gen 120:341353.

Said-Al AH, Mahmoud AA. 2010. Effect of zinc and/or iron foliar application on growth and essential oil of Sweet basil (Ocimum basilicum L.) under salt stress. Ozean J App Sci 3:97-111.

Sarmoum R, Haid S, Biche M, Djazouli Z, Zebib B. 2019. Effect of Salinity and Water Stress on the Essential Oil Components of Rosemary (Rosmarinus officinalis L.). Agronomy 9 (5): pp214.

Shafieizargar A, Awang Y, Juraimz AS, Othman R. 2013. Comparative studies between diploid and tetraploid Dez Orange (Citrus sinensis (L.) Osb.) under salinity stress. Aus J Crop Sci 7:1436-1441.
Shalan MN, Abdel-Latif TAT, Ghadban EA. 2006. Effect of water salinity and some nutritional compounds of the growth and production of sweet marjoram plants (majorana hortensis L.). Egypt J Agric Res 84:959.

Sharafi Y, Talebi S.F, Talei D. 2017. Effects of heavy metals on male gametes of sweet cherry. Caryologia 70(2): 166-173.

Tabatabaie S.J, Nazari J, Nazemiyeh H, Zehtab S, Azarmi F. 2007. Influence of various electrical conductivity levels on the growth and essential oil content of Peppermint (Mentha piperita L.) grown in hydroponic. Act Hort 747:197-201.

Talebi SF, Saharkhiz MJ, Jafarkhani Kermani M, Sharafi Y, Raouf Fard F. 2017. Effect of different antimitotic agents on polyploidy induction of anise hyssop (Agastache foeniculum L.). Caryologia doi.org/10.108 0/00087114.2017.1318502.

Tseng MJ, Liu CW, Yiu JC. 2007. Enhanced tolerance to sulfur dioxide and salt stress of transgenic Chinese cabbage plants expressing both superoxide dismutase and catalase in chloroplasts. Plant Phy Bio 45:822833.

Tu Y, Jiang A, Gan L, Hossain M, Zhang J, Peng B, Y Xiong, Z Song, Cail D, Xu W, Zhang J, He Y. 2014. Genome duplication improves rice root resistance to salt stress. Rice 7:15. doi.10.1186/s12284-014-0015-4.

Van Laere K, França S, Vansteenkiste H, Van Huylenbroeck J, Steppe K, Van Labeke MC. 2010. Influence of ploidy level on morphology, growth and drought susceptibility in Spathiphyllum wallisii. Acta Phy Plant 33:1149-1156.

Wang Z, Wang M, Liu L, Meng F. 2013. Physiological and proteomic responses of diploid and tetraploid Black locust (Robinia pseudoacacia L.) subjected to salt stress. Mol Sci 14:20299-20325.

Yancey PH, Clark M E, Hand SC, Bowlus RD, Somero GN. 1982. Living with water stress: evolution of osmolyte systems. Science 217:1214-1222.

Zhang B. 2015. MicroRNA: A new target for improving plant tolerance to abiotic stress. J Exp Bot 66:17491761.

Zhang F, Xue H, Lu X, Zhang B, Wang F, Ma Y, Zhang Z. 2015. Autotetraploidization enhances drought stress tolerance in two apple cultivars. Trees 29:1773-1780. doi. 10.1007/s00468-015-1258-4.

Zhang XY, Hu CG, Yao JL. 2010. Tetraploidization of diploid Dioscorea results in activation of the antioxidant defense system and increased heat tolerance. Plant Phy 167:88-94. 